\title{
Hope and Despair in First-Year Medical Students
}

\author{
Norma Yepez, Ileana Petra, Beatriz Zamora, Mariana Fouilloux, Maria Martina Jurado* \\ Psychiatry and Mental Health Department, Faculty of Medicine, National Autonomous University of Mexico, Mexico City, Mexico \\ Email address: \\ normayepez@yahoo.com.mx (N. Yépez), ileanapetra@yahoo.com (I. Petra), beatriz.zamora98@gmail.com (B. Zamora), \\ mar_fou@hotmail.com (M. Fouilloux), idamar007@gmail.com (M. M. Jurado) \\ ${ }^{*}$ Corresponding author
}

\section{To cite this article:}

Norma Yepez, Ileana Petra, Beatriz Zamora, Mariana Fouilloux, Maria Martina Jurado. Hope and Despair in First-Year Medical Students. American Journal of Applied Psychology. Vol. 9, No. 1, 2020, pp. 7-13. doi: 10.11648/j.ajap.20200901.12

Received: January 14, 2020; Accepted: January 27, 2020; Published: February 11, 2020

\begin{abstract}
The transition of high school to university, as well as accustoming to new peers and teachers, requires a more exceptional ability for students to adapt. Besides, as academic demands and stress increase, some students become more overwhelmed with exams or other requirements, causing despair to appear or accentuate. In some cases, this situation is related to their youth, which can reinforce negative attitudes, as well as anxiety and depression or even, make them feel like they made a wrong decision about choosing their career. This study aims to know the characteristics of hope and despair in first-year medical students that are about to finish the school year. On the other hand, it was necessary to adapt and validate the clinic characteristics of the Hope-Despair Test of Mario Ramón Pereyra to the student population, including a factorial analysis. Results of the factor analysis of the Hope scale, with 11 items, showed a .825 Cronbach Alpha, with two factors explaining $47.8 \%$ of the variance. Factor one was called Expectancy, while the second was called Coping. The Despair scale showed a .847 Cronbach Alpha, with three factors that explained $59.95 \%$ of the variance. Factor one was called Pessimism, the second Distrust, and the third Regression. In the Expectancy factor, most students tend to look forward to the future and believed they could achieve what they propose $(80.2 \%)$. In the Copping factor, more than half of the students considered that they can keep making an effort despite adversity, are open to new situations, and tend to be productive. In the scale of Despair, although more than half (50 to $85.8 \%)$ hoped for the best, just over the third part was afraid that terrible things might happen in their future. These results emphasize that almost a quarter are easily discouraged and depressed; $9.5 \%$ reported thinking that their life was meaningless, and $4.6 \%$ have thought of ending their lives. Women scored lower in coping than men. Students mentioned the importance of living at home with their parents as well as having mothers who attended higher education. It is stated that the institutions must offer support to students who tend to despair.
\end{abstract}

Keywords: Medical Students Hope, Despair, Pessimism, Distrust, Regression

\section{Introduction}

The interest in studying despair in first-year medical students stems from the psychological care services provided to young people, where it has been identified that adapting to a new educational level and the academic demands of the career, forces the student to make a significant effort to adequately organize their study times and manage strategies that allow them to complete standardized assessments so they can be accredited and to maintain adequate school grades, considering that it is necessary to study and memorize a large amount of information.
The process of transition from high school to university and adapting to new peers and teachers requires a greater ability for students to adjust. Nevertheless, as time, academic demands, and pressures progress, some students become more overwhelmed and cause despair to appear or accentuate. In some cases, this situation is related to their youth, which can reinforce negative attitudes, anxiety, and depression or even making them feel like they made a wrong decision about choosing their career.

The concept of despair was initially described by Seligman [1], who used an animal model to study the relationship between fear and learning avoidance. With this model, he identified that dogs developed a series of behaviors and 
neurochemical changes similar to those presented in depression. This phenomenon was named "helplessness" or "learned helplessness" and stated that it has cognitive, motivational, and behavioral components.

Later, Abramson and Seligman [2] defined despair as a negative expectation about the appearance of an event considered as important, linked to a sensation of helplessness about the possibility of changing the occurrence of that event. Therefore, the helplessness or learned despair consists of a subjective feeling interpreted as intellectual inertia where the individual learns to behave passively, believing that he cannot do anything even though there are real opportunities to change an adverse situation [3].

If a person frequently has these symptoms, they may develop a major depressive episode since this condition induces a helplessness state that can lead to reduce or cancel extrinsic motivation since they cannot achieve positive results or avoid negative ones [4].

In a similar case, Wilcox [5] investigated the relationship between the level of despair and the possibility of planning towards the future in college students. He concluded that the student with fear could develop a negative perception of himself and a poor academic performance that can lead to a state of despair that, included in their behavior, could be negatively reflected on their future scholarly productivity.

Positive Psychology has approached the issue of learned despair and emphasizes the importance of balancing positive and negative information by contrasting psychological resources and difficulties [6]. Positive emotions about the future include faith, confidence, hope, and optimism. The latter two are aspects that improve resistance to depression, boost work performance, and physical health if they are developed [7].

This research focuses on the study of the hope-despair binomial, which constitutes an aspect of the individual that has been of particular interest in clinical and educational research in recent decades.

Among the definitions found in literature about the concept of hope-despair, authors such as Pereyra [8], consider that hope is always transcendent, and goes beyond all present and reality, opening the horizons of the future to what is beneficial, and to the well-known forces of life. So, according to this author, hope is not subjected to pressures or drastic decisions but takes with it the freedom of action and somehow maintains the stability and motivation to continue in the struggle.

Reference [9] conducted a longitudinal study with students for six years until they graduated college and concluded that students with high levels of hope were more likely to graduate compared to those who showed low levels of hope.

In another study conducted by Pereyra and Aragon [10], it was studied the association between academic success and variables such as personality and family in a sample of 162 students, finding that hope tend to predict academic achievement, without statistical significance. In 2008, Pereyra [11] investigated positive emotions, satisfaction with life, and hope-despair in a sample of 613 individuals, including the Mexican and Haitian population. Hope was linked with positive emotions and satisfaction with life; meanwhile, despair was associated with negative emotions.

Using the Hope and Despair test (TED in Spanish), Muñoz and Morales [12] assessed university students to find out if working on self-knowledge and personal development in group sessions improve functional and adaptive personality styles and if they enhanced hope and self-esteem. They used the Millon personality styles test [13], the Hope-Despair Test (TED) [14], and the Rosemberg Self-Esteem Questionnaire [15]. The evaluation was carried out in the test-post-test modality, and the analysis of the results showed a significant increase in hope and self-esteem levels as well as in the representative scores of functional personality styles.

Pereyra [16] proposes an explanation of the hope-despair construct that suits the characteristics of the studied population. This author considers it as a dialectical and dramatic process with a multidimensional and multifaceted character. Dialectical because it considers hope and despair as polarized alternatives in a dynamic process and constant tension, that shape a continuous gradual spectrum with multiple intermediate forms, and requests and invites each person to choose between hope and their opposite. This concept about hope-despair does not propose them as dissociated or exclusionary attitudes or behaviors.

The test designed by Pereyra [14] was considered

appropriate because its items were related to the areas that were intended to know in medical students.

This study searches for the characteristics of hope and despair in first-year medical students that are about to end the school year.

\section{Method}

This is a cross-sectional, descriptive study. The sample was randomly formed of 388 first-year medical students of the National Autonomous University of Mexico. 69.3\% were women. $94.3 \%$ were 17 years old or younger at the time of the study, and $94.6 \%$ studied in public high middle schools. The TED was applied in their classroom towards the end of the school year. Students were told of the nature of the study, and the informed consent was obtained based on the suggestions made by Loue [17].

Pereyra's Hope-Despair Test [14] consists of 28 items divided into three scales (global, hope, and despair). Each item has five response options that range from 0 (never) to 4 (always). Validation studies have shown high scores in Cronbach's alpha coefficient (0.89 and 0.90). The dimensions that the author of the test proposed regarding the hope scale are optimism and prospecting, and in the despair scale, 
pessimism, regression, mistrust, and fatalism.

At the beginning of this study, it was considered unnecessary to adapt the test to the specific characteristics of the population. However, afterward, it was deemed to be important due to some modifications. Therefore, the Cronbach Alpha and the major components of the factorial analysis through the Varimax rotation were obtained.

Besides, the descriptive analysis was performed with frequencies and percentages of the students' answers. Also, the scores obtained on the Hope and Despair scales were compared by sex, age, the school where they came from, high school grades, people with whom they live, and the mother's education. The Mann-Whitney and Kruskal Wallis U-tests were used since the data obtained were not normally distributed.

\section{Results}

As a result of the factor analysis of the Hope scale, two of the thirteen items were removed. With the remaining 11 items, it was obtained a Cronbach's Alpha of .825. Two factors explained $47.8 \%$ of the variance. Factor 1 was called Expectancy, while the second was called Coping (Table 1).

Table 1. Factorial saturations of the 11 items on the TED Hope Scale.

\begin{tabular}{lll}
\hline \multirow{2}{*}{ Item } & Factors & Coping \\
\cline { 2 - 3 } & Expectancy & .692 \\
\hline I feel like I still have very important things to do in my life. & .689 \\
I look at tomorrow, placing my trust in the future. & .664 \\
I have faith that everything will get better in the end. & .642 \\
I have goals I hope I can achieve. & .616 \\
I enjoy each day and want to live life to the fullest. & .556 \\
In moments of intense anguish and suffering, hope helps me overcome them. & .536 \\
With some help, I believe it is possible to achieve what one proposes to do. & \\
I quickly adapt to new situations in life. & \\
I try to do something useful and productive every day. & \\
Instead of breaking me down, adversity and problems stimulate me to fight to go on. \\
I feel attracted to new projects and the possibility of creating different things.
\end{tabular}

Two of the fifteen items from the Despair scale were removed. With the remaining 13, it was obtained a Cronbach's Alpha of .847 , with three factors that explained $59.95 \%$ of the variance. Factor 1 was called Pessimism, the second Distrust, and the third Regression (Table 2).

Table 2. Factorial saturations of the 13 items on the TED's Despair scale.

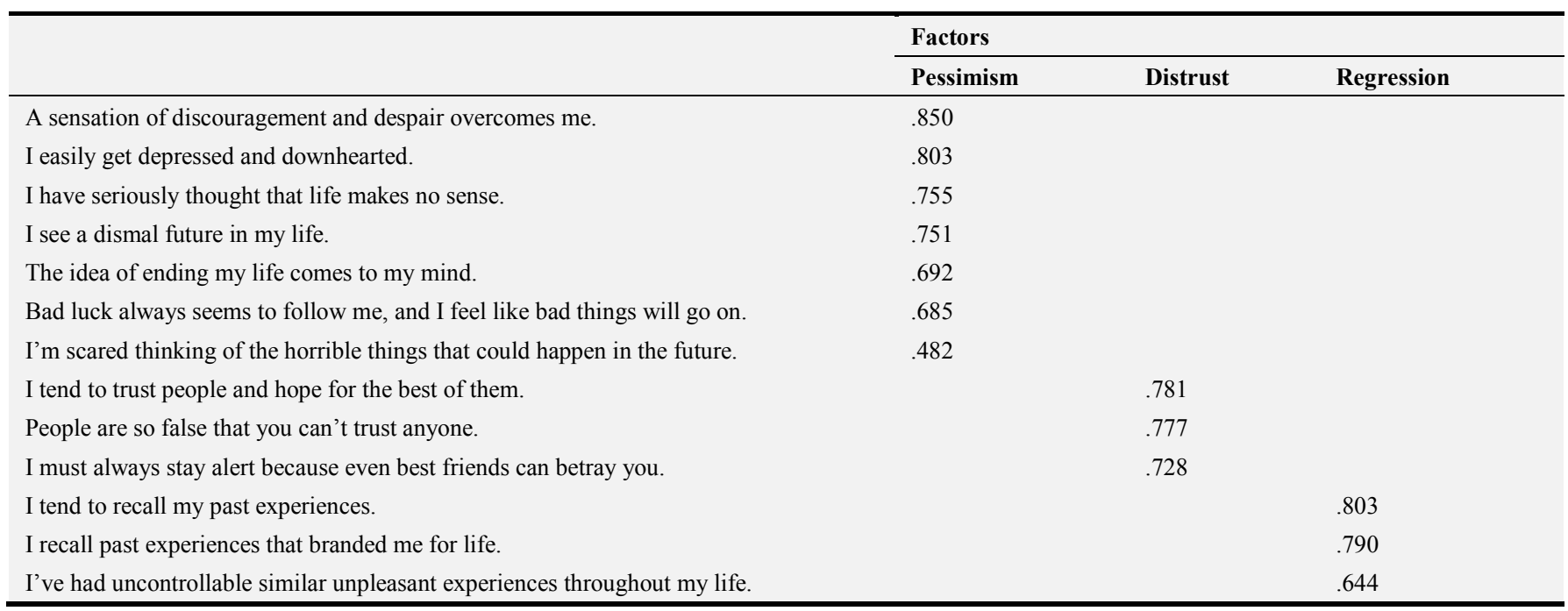

The elimination of items from both scales was because, during the factorial analysis, they presented saturation factors below .400 .

In the Expectancy factor of the Hope Scale, most students tended to see towards the future, where it is remarkable the item regarding students believing they can accomplish their purposes $(80.2 \%)$. It is also noted that between $59.3 \%$ and $97.7 \%$ of students were able to expect the best of circumstances (Table 3).

In the Copping factor, more than half of the students considered they can often keep making an effort despite adversities, are open to new situations, and tend to be 
productive (Table 3$)$.

Table 3. Descriptive analysis of the Hope scale in first-year medical students ( $n=388)$.

\begin{tabular}{|c|c|c|c|c|c|c|}
\hline \multirow{3}{*}{ Expectancy } & \multicolumn{6}{|c|}{ How often they identify with each situation } \\
\hline & \multicolumn{2}{|c|}{ Frequently or always } & \multicolumn{2}{|c|}{ Sometimes } & \multicolumn{2}{|c|}{ Rarely or never } \\
\hline & $\mathbf{f}$ & $\%$ & $\mathbf{f}$ & $\%$ & $\mathbf{f}$ & $\%$ \\
\hline I have faith that everything will get better in the end. & 289 & 74.5 & 84 & 21.6 & 15 & 3.9 \\
\hline I have goals that I expect to achieve. & 379 & 97.7 & 5 & 1.3 & 4 & 1.0 \\
\hline I enjoy each day and want to live life to the fullest. & 302 & 77.8 & 74 & 19.1 & 12 & 3.1 \\
\hline I still feel like I have very important things to do in my life. & 338 & 87.1 & 36 & 9.3 & 14 & 3.6 \\
\hline With some help, I believe it's possible to achieve what I propose to do. & 311 & 80.2 & 64 & 16.5 & 13 & 3.4 \\
\hline In moments of intense anguish and suffering, hope helps me overcome them. & 230 & 59.3 & 118 & 30.4 & 40 & 10.3 \\
\hline I look at tomorrow, placing my trust in the future. & 232 & 59.8 & 111 & 28.6 & 45 & 11.6 \\
\hline \multicolumn{7}{|l|}{ Coping } \\
\hline I feel attracted to new projects and the possibility of creating different things. & 320 & 82.5 & 59 & 15.2 & 9 & 2.3 \\
\hline Instead of breaking me down, adversity and problems stimulate me to fight to go on. & 231 & 59.8 & 132 & 34.0 & 24 & 6.2 \\
\hline I try to do something useful and productive every day. & 269 & 69.3 & 109 & 28.1 & 10 & 2.6 \\
\hline It is easy for me to adapt to new situations. & 214 & 55.2 & 153 & 39.4 & 21 & 5.4 \\
\hline
\end{tabular}

When analyzing the Despair Scale, it was observed in the Pessimism factor that, although more than half (50 to 85.8\%) of the participants tended to hope for the best, over a third were afraid that terrible things might happen in their future. These results emphasize that almost a quarter are discouraged and can easily get depressed. On the other hand, 9.5\% thought their life is meaningless, and $4.6 \%$ have thought of ending their lives (Table 4).

Within the same Despair Scale, the Regression factor identified a high percentage of students who frequently tended to think about the past. Finally, in the Mistrust factor, less than $20 \%$ of students reported experiencing insecurity and poor social and moral support (Table 4).

Table 4. Descriptive analysis of the Despair scale in first-year medical students ( $n=388$ ).

\begin{tabular}{|c|c|c|c|c|c|c|}
\hline \multirow{3}{*}{ Pessimism } & \multicolumn{6}{|c|}{ How often they identify with each situation } \\
\hline & \multicolumn{2}{|c|}{$\begin{array}{l}\text { Frequently or } \\
\text { always }\end{array}$} & \multicolumn{2}{|c|}{ Sometimes } & \multicolumn{2}{|c|}{ Rarely or never } \\
\hline & f & $\%$ & f & $\%$ & f & $\%$ \\
\hline An overpowering sensation of discouragement and hopelessness overcomes me. & 59 & 15.2 & 101 & 26.0 & 228 & 58.8 \\
\hline I have seriously thought that life makes no sense. & 37 & 9.5 & 65 & 16.8 & 286 & 73.7 \\
\hline I see a dismal future in my life. & 21 & 5.4 & 74 & 19.1 & 293 & 75.5 \\
\hline Bad luck always seems to follow me, and I feel like bad things are going to will go on. & 21 & 5.4 & 71 & 18.3 & 296 & 76.3 \\
\hline I easily get depressed and downhearted. & 91 & 23.5 & 103 & 26.5 & 194 & 50.0 \\
\hline The idea of ending my life comes to my mind. & 18 & 4.6 & 37 & 9.5 & 333 & 85.8 \\
\hline I'm scared of the horrible things that could happen in the future. & 129 & 33.2 & 109 & 28.1 & 150 & 38.7 \\
\hline \multicolumn{7}{|l|}{ Distrust } \\
\hline People are so false that you can't trust anyone. & 48 & 12.4 & 116 & 29.9 & 224 & 57.7 \\
\hline I tend to trust people and hope for the best of them. & 68 & 17.5 & 116 & 29.9 & 204 & 52.6 \\
\hline I must always stay alert because even best friends can betray you. & 43 & 11.1 & 58 & 14.9 & 287 & 74.0 \\
\hline \multicolumn{7}{|l|}{ Regression } \\
\hline I've had uncontrollable similar unpleasant experiences throughout my life. & 77 & 19.8 & 91 & 23.5 & 220 & 56.7 \\
\hline I tend to recall past experiences that branded me for life. & 143 & 36.9 & 124 & 32.0 & 121 & 31.2 \\
\hline I tend to recall my past experiences. & 192 & 49.5 & 132 & 34.0 & 64 & 16.5 \\
\hline
\end{tabular}

With the Mann-Whitney $U$ test, statistically significant differences were found in the Hope Scale, where women reported less ability to face and recover from adverse situations $(\mathrm{Me}=11)$ than men $(\mathrm{Me}=12)(\mathrm{Z}=-2.003 ; \mathrm{p}=.045)$. Also, students over 17 years old $(M=13)$ showed greater development in these skills than younger students $(Z=-2.012$, $\mathrm{p}=0.44)$.

In the case of despair, when conducting the Kruskal-Wallis test, statistically significant differences were found on the global scale when comparing scores of the variable "people who live with the student" $\left(X^{2}=19.26 ; p=.001\right)$. After considering Bonferroni's correction test, it was identified that students who lived with other relatives $(\mathrm{Me}=15)$ reported less despair than those who lived with peers $(\mathrm{Me}=21)$ (adjusted significance of .046).

It was also observed in the Pessimism factor $\left(X^{2}=16.67\right.$; 
$\mathrm{p}=.002)$, that those who lived with both parents $(\mathrm{Me}=7)$ manifested a lower score in this characteristic than those who lived with only one of them $(\mathrm{Me}=9)$ (adjusted significance of .018). Those who lived with both parents $(\mathrm{Me}=7)$ showed less pessimism than those who live with other partners $(\mathrm{Me}=10)$ (adjusted meaning of .040). In the same way, those who lived with other relatives $(\mathrm{Me}=6)$ reported less pessimism than those living with peers $(\mathrm{Me}=10)$ (adjusted meaning of .029).

As for the mother's education, differences with statistical significance were observed in the Pessimism factor $\left(\mathrm{X}^{2}=10.54 ; \mathrm{p}=.015\right)$, where students whose mothers completed high school or equivalent $(\mathrm{Me}=8)$ showed greater pessimism than those with mothers with graduate and postgraduate studies $(\mathrm{Me}=6)$ (adjusted significance of .015).

\section{Discussion}

In this study, the psychometric properties of TED were examined. Unlike the author of the scale, this analysis found a factorial structure of 5 factors since the items of fatalism were associated with the ones of pessimism, being included as a single factor. This can be explained by the close relationship between the two concepts as they refer to expecting the worst and that nothing can improve.

In this sense, it was found that most students presented high expectancy and coping and low pessimism and distrust. Hence, according to Seligman's proposal [7], it is noted that although individuals can maintain positive emotions, their despair is not enhanced by the school stress they experience. In this case, motivation towards being able to go to college is likely to play a protective role in facing stress. As González and Hernández [4] proposed, motivation and despair are related; therefore, managing the motivations helps to manage despair.

Although most students did not show despair, it is remarkable that a significant percentage was afraid that unpleasant things might happen in their future, which is related to items associated with fatalism, and that can be a result of the stress they face but tend to control. Reference [18] found that fatalism is associated with the psychological impact of severe stress, which may limit some individuals' ability to feel in control of the situation. It is essential to mention that some students expressed emotional discomforts such as discouragement, feeling like life loses its meaning, and even a desire to end their life. In line with this, Wilcox [5] reported that a student with fear could develop negative emotions, so monitoring and attending the first-year students' mental health is indispensable.

It is relevant to mention that the researchers of this study contacted these students so a psychiatrist could evaluate them and, if they needed Psychiatric attention, they were registered in a Mental Health Program, offered at the Faculty of Medicine, within the Department of Psychiatry and Mental Health.

Another interesting finding was that women had lower scores in coping than men. However, it must be considered that the coping strategies of the scale refer to active planning and coping associated with cognitive and behavioral aspects, which, according to Cabanach, R. G., Fariña, F., Freire, C., González, P. \& del Mar Ferradás, M. [19], are most frequently observed in men. On the other hand, other studies show that women who tend to present more pessimistic thoughts have twice the likelihood of suffering from depression than men. Besides, women generally think more about their problems, which may increase their depression, and as Seligman mentions (2006), pessimism is a risk factor for depression. Research has also pointed out that women tend to focus more on immediate goals and are more pessimistic about their future than males [20].

It should be highlighted that high scores are observed in the regression factor that is not related to the scores of the other two factors of the despair scale. This finding may be related to previous events that the student considers relevant but does not provoke a negative view of life or other people.

Guzmán [21] shows that when the mother has a high level of education (middle education or higher), the children are more likely to access a college education, possibly because she can support and help them economically and academically. This precedent relates to the results of this study, where students whose mothers with high school education or more, show less pessimism. This finding is also corroborated by what Hamaideh and Hamdan-eMasour [22] reported, where they found that students whose mothers attended university develop more favorable academic expectations than those whose mothers only attended elementary education.

The social network support is another crucial factor, as in the case of students who live with both parents, where they showed less pessimism than those who live only with a parent or peers. It was also observed that living with family members is related to less despair than living with peers, so the family has a protective role in the mental health of individuals [23].

Research in the educational field has made contributions to learning, concluding that it is a process in which in addition to cognitive-intellectual factors, emotional-affective and social factors also influence the learning process and its results. In higher education, the emotional and social factors are rarely contemplated, since they are not considered necessary because the students are already adults and therefore, out of the teenage instability phase. However, there is evidence that emotions play a crucial role in achieving training goals as well as in academic learning, no matter what age [24].

Therefore the low scores on coping in 17-year-old students or younger can be explained by what has been reported in other studies, where it has been observed that adolescents put greater importance on their peer relationships, affirmation, and sociability, On the contrary, people of 18 years old and over must achieve goals that bring them closer to their adult life, with it the responsibilities that this entails, according to the social tasks they are required [25]. 


\section{Conclusions}

According to the background and results found, this study agrees with Muñoz and Morales [12] on the importance of implementing workshops or courses aimed at students to develop more adaptive coping strategies, promote better problem-solving mechanisms, and thus prevent academic difficulties or alterations in their mental health.

Workshops can be considered a way to prevent the appearance of future problems if they are intended to promote the development of positive emotions such as motivation, organization, and optimism, among others.

From a positive psychology perspective, the contribution of this research lies in the importance of detecting protective factors that can help prevent poor academic performance in medical students, as well as prevent the development of depressive symptomatology in this population.

On the other hand, the results of this study also allow us to show the importance of promoting and offering the university's medical-psychological support programs to students with high levels of despair, where the interventions are aimed to manage their emotions. Therefore, according to what Pereyra [11] mentioned, encouraging a better selfconcept promotes greater hope.

It would be appropriate to study in the future the level of influence that the peer group can have in supporting students to face the demands that the career implies and could also be considered a protective factor against stress and despair if adequately promoted.

\section{Acknowledgements}

This study was not funded by any grants. We want to express gratitude to Dr. Mario Ramón Pereyra Lavandina for his support.

\section{Conflict of Interest}

All the authors do not have any possible conflicts of interest.

\section{References}

[1] Seligman, M. E. P. (1975). Helplessness: On depression development and death. San Francisco: W. H. Freeman \& Co. Ltd.

[2] Abramson, L. \& Seligman, M. E. P. (1978). Learned helplessness in humans: Critique and reformulation. Journal of Abnormal Psychology, 87 (1), 49-74.

[3] Morales, N. (2018). Esperanza-Desesperanza: Una etnografía de las colas. Fermentum, Revista Venezolana de Sociología y Antropología, 28 (82).

[4] González, J. \& Hernández, A. (2012). La desesperanza aprendida y sus predictores en jóvenes: Análisis desde el modelo de Beck. Enseñanza e Investigación en Psicología, 17 (2), 313-327.

[5] Wilcox, M. R. (2011). Factores de Riesgo y protección para el rendimiento académico. Un estudio descriptivo en estudiantes de psicología de una universidad privada. Revista Iberoamericana de Educación, 55 (1), 1-9.

[6] López, S. J. \& Magyar-Moe, J. L. (2006). A positive psychology that matters. The Counseling Psychologist, 34 (2), 323-330.

[7] Seligman, M. E. P. (2003). "La auténtica felicidad: La nueva psicología positiva revoluciona el concepto de felicidad y señala el camino para perseguirla”. Barcelona: Ediciones B.

[8] Pereyra, M. R. (1997). Psicología de la esperanza con aplicaciones a la práctica clínica. Buenos Aires: Psicoteca.

[9] Snyder, C., Rand, K., King, E., Feldman, D. \& Woodward, J. (2002). False hope. Journal of Clinical Psychology, 58 (9), 1003-1022.

[10] Pereyra, M. R. \& Aragón, A. (2006). Éxito académico, variables de personalidad y de familia: Estudio de seguimiento de 3 años. Revista Mexicana de Psicología, número especial, 217-218.

[11] Pereyra, M. R. (2008). Emociones positivas, satisfacción con la vida y esperanza-desesperanza: Estudio transcultural (Haití y México). Revista Mexicana de Psicología, número especial, 114-115.

[12] Muñoz, E. N., \& Morales, C. (2008). Grupos de autoconocimiento: Recurso para favorecer el desarrollo personal. Fundamentos en Humanidades, 17 (1), 163-178.

[13] Millon, T. (1997). MIPS: Inventario Millon de Estilos de Personalidad. Buenos Aires, Paidós.

[14] Pereyra, M. R. (2014). Esperanza-Desesperanza TED-TED-R Manual. México: Manual Moderno.

[15] Rosenberg, M. (1966). Society and the adolescent self-image. Princeton, NJ: Princeton, University Press.

[16] Pereyra, M. R. (2006). Psicología positiva, cómo abrir los horizontes del futuro. Lima: Universidad Peruana Unión.

[17] Loue, S. (2006). Aspectos éticos de los estudios multicéntricos. En: F. Lolas, A. Quezada \& E. Rodríguez (Eds.). Investigación en salud: Dimensión ética (pp. 273-278). Chile: CIEB, Universidad de Chile.

[18] Belmar, D., Bontes, M., Levi, Y., Moreno, J. P. \& Rehbein, L. (2012). Estrés post-traumático, locus de control y fatalismo en adultos afectados por el terremoto del 27 de febrero en la ciudad de Angol. Salud \& Sociedad, 3 (1), 10-18.

[19] Cabanach, R. G., Fariña, F., Freire, C., González, P. \& del Mar Ferradás, M. (2013). Diferencias en el afrontamiento del estrés en estudiantes universitarios hombres y mujeres. European Journal of Education and Psychology, 6 (1), 19-32.

[20] Omar, A. (2005). Las perspectivas del futuro y sus vinculaciones con el bienestar y la resiliencia en adolescentes. Psicodebate, Psicología, cultura y sociedad. Vol. 7.

[21] Guzmán-Gómez, C. \& Serrano-Sánchez, O. V. (2011). Las puertas del ingreso a la educación superior: El caso del concurso de selección a la licenciatura de la UNAM. Revista de la Educación Superior XL, 1 (157), 31-53.

[22] Hamaideh, S. \& Hamdan_Masour, A. (2014). Psychological, cognitive and personal variables that predict college academic achievement among health sciences students. Nurse Educ Today, 34, 703-708. 
[23] Haquin, C., Larraguibel, M. \& Cabezas, J. (2004). Factores protectores $\mathrm{y}$ de riesgo en salud mental en niños y adolescentes de la ciudad de Calama. Rev Chil Pediatr, 75 (5), 425-433.

[24] Schutz, P. \& Pekrun, R. (2007). Emotion in education. San Diego CA: Academic Press.
[25] Martínez-Correa, A., Reyes del Paso, G., García-León, A. \& González-Jareño, M. (2006). Optimismo/pesimismo disposicional y estrategias de afrontamiento del estrés. Psicothema, 18 (1), 66-72. 